\title{
PEMBUATAN PETA BLOK RT DESA BINGKULU KECAMATAN TAMBANG ULANG
}

\author{
Nurul Inayah ${ }^{1}$, Ferry Sobatnu ${ }^{2}$, Faris Ade Irawan ${ }^{3}$, Dewi Nur Indah Sari ${ }^{4}$ \\ Politeknik Negeri Banjarmasin ${ }^{1234}$ \\ inayah_nurul@poliban.ac.id ${ }^{l}$ \\ sobatnu@poliban.ac.id ${ }^{2}$ \\ faris.irawan@poliban.ac.id ${ }^{3}$ \\ dewi.sari@poliban.ac.id ${ }^{4}$
}

\begin{abstract}
Geodetic science is practically making maps of the earth's surface. Bingkulu village currently has problems with the absence of a village map for village government officials and local residents. The absence of this village map made difficulties for village and community equipment to find out information on Neighborhood Association boundaries and land use in the Bingkulu Village area at Tambang Ulang District. To make a map of the Neighborhood Association boundaries, using survey method with a GPS handheld equipment and identifies the Neighborhood Association boundaries according to the direction from the village officials who is very familiar with the conditions in the field. Making Neighborhood Association boundary maps is done through digitizing in the QGIS application by displaying corrected satellite images. Through the QGIS application, digitization is carried out in accordance with the conditions in the research location, by paying attention to the appearance of the earth in the satellite image of Bingkulu Village. The objects digitized in this process are roads, Neighborhood Association boundaries, village boundaries, public facilities. Furthermore the interpretations did and the result is that land use in Bingkulu Village includes plantations, rice fields, and built land. The Plantations distributed in almost the Bingkulu region with two types of commodities, namely oil palm and rubber trees. In addition, land use in all Bingkulu region is dominated by oil palm plantations. So that oil palm trees are still the main commodity of plantations in Bingkulu Village.
\end{abstract}

Keywords: survey, satellite image, boundary, village

\begin{abstract}
ABSTRAK
Ilmu geodesi secara praktis adalah membuat peta dari sebagian besar atau sebagian kecil permukaan bumi. Desa Bingkulu saat ini memiliki permasalahan belum adanya peta desa bagi aparat pemerintah desa maupun warga masyarakat setempat. Ketiadaan peta desa ini menyulitkan perangkat desa dan masyarakat untuk mengetahui informasi batas RT dan penggunaan lahan di wilayah Desa Bingkulu, Kecamatan Tambang Ulang, Kabupaten Tanah Laut. Untuk membuat peta batas RT di atas dilakukan dengan survei menggunakan GPS handheld mengelilingi dan mengidentifikasi batas RT sesuai arahan salah satu aparat desa yang sangat menguasai kondisi di lapangan. Pembuatan peta batas RT dilakukan memalui proses digitasi pada Aplikasi QGIS dengan menampilkan citra satelit yang sudah terkoreksi. Melalui aplikasi QGIS, digitasi dilakukan sesuai dengan kondisi dan keadaan di lokasi penelitian, dengan memperhatikan kenampakan rupa bumi pada citra satelit Desa Bingkulu. Adapun obyek yang didigitasi pada proses ini yaitu jalan, batas RT, batas desa, fasilitas umum. Selain itu interpretasi dilakukan dan didapatkan bahwa penggunaan lahan di Desa Bingkulu meliputi perkebunan, sawah, dan lahan terbangun. Penggunaan lahan berupa perkebunan hampir merata diseluruh wilayah Desa Bingkulu
\end{abstract}


dengan dua jenis komoditas yaitu pohon sawit dan karet. Selain itu penggunaan lahan di seluruh wilayah Desa Bingkulu didominasi oleh perkebunan sawit. Sehingga pohon sawit sampai saat ini masih menjadi komoditas utama dari perkebunan yang ada di Desa Bingkulu.

Kata Kunci: survei, citra satelit, batas, desa

\section{PENDAHULUAN}

\section{Latar Belakang}

Ilmu geodesi mempunyai dua maksud yaitu yang pertama secara ilmiah adalah menentukan bentuk permukaan bumi dan yang kedua secara praktis adalah membuat peta dari sebagian besar atau sebagian kecil permukaan bumi. Survei didefinisikan sebagai pengumpulan data yang berhubungan dengan pengukuran permukaan bumi dan digambarkan melalui peta. Pekerjaan mengukur tanah dan pemetaan (survei dan pemetaan) meliputi pengambilan/pemindahan data dari lapangan ke peta atau sebaliknya.

Desa/kelurahan sebagai satuan wilayah tata usaha pendaftaran tanah mutlak memerlukan batas wilayah administrasi yang sah, jelas, tegas dan tidak ada sengketa. Permasalahan yang dihadapi kantor pertanahan adalah ketersediaan data dan informasi peta desa sangat terbatas dan tidak up to date. Proses peta desa sesuai prosedur baku membutuhkan waktu yang relatif lama. Di sisi lain, ketersediaan informasi peta desa bagi aparat pemerintah desa maupun warga di lokasi tersebut sangat penting dan mendesak.

Desa Bingkulu saat ini memiliki permasalahan belum adanya peta batas RT desa bagi aparat pemerintah desa maupun warga masyarakat setempat. Ketiadaan peta desa ini menyulitkan perangkat desa dan masyarakat untuk mengetahui informasi batas RT dan penggunaan lahan di wilayah Desa Bingkulu, Kecamatan Tambang Ulang, Kabupaten Tanah Laut.

\section{Tujuan dan manfaat kegiatan}

Berdasarkan latar belakang yang telah dijelaskan pada bab sebelumnya, bahwa pelaksanaan pengabdian masyarakat ini adalah memberikan pelayanan kepada Masyarakat dalam bentuk kajian dan tindakan/penerapan keilmuan yang dapat bermanfaat secara langsung bagi Masyarakat. Dharma pengabdian pada Masyarakat harus diartikan dalam rangka penerapan ilmu pengetahuan dan teknologi yang didapat di perguruan tinggi sebagai konstribusi terhadap masyarakat yang bersifat kongkrit dan langsung dirasakan manfaatnya.

Manfaat yang didapat dari kegiatan ini yaitu menyediakan informasi batas RT dan penggunaan lahan di wilayah Desa Bingkulu, Kecamatan Tambang Ulang, Kabupaten Tanah Laut.

\section{STUDI LITERATUR}

\section{Survey dan Pemetaan}


Menurut (sobatnu, 2006). Ilmu geodesi pada artian tingkat rendah adalah merupakan suatu rangkaian kegiatan penentuan posisi yang pasti dari tempattempat di permukaan bumi melalui proses pengukuran dan pengamatan yang bersipat konvensional terrestrial atau biasa dikenal dengan Survey dan Pemetaan. Berdasarkan uraian tersebut dapat didefinisikan bahwa;

1. Survey merupakan kegiatan pengumpulan data berupa posisi, bentuk, luasan, ukuran dari sebagian kecil ataupun sebagian besar permukaan bumi melalui proses pengukuran dan pengamatan.

2. Pemetaan adalah tahapan penyajian informasi dari kondisi nyata permukaan bumi (fakta real) yang terdiri dari unsur alami dan buatan manusia dengan menggunakan simbol-simbol dalam skala dan sistem proyeksi tertentu. Rangkaian kegiatan survey dan pemetaan tersebut dilakukan secara langsung di lapangan dengan teknik dan perhitungan tertentu serta peralatan yang tentu pula.

Dalam hal ini pengukuran dilakukan pada permukaan bumi mencakup unsur tiga dimensi yaitu penentuan koordinat-koordinat (X, Y, Z). Koordinat tersebut dapat dijadikan Kerangka Kontrol. Koordinat tiga dimensi tersebut dua dimensinya diperoleh melalui pengukuran panjang sumbu $x$ dan sumbu $y$ pada bidang mendatar, perpotongan garis proyeksi dari kedua sumbu tersebut digunakan untuk menyatakan titik di lapangan. Rangkaian titik yang telah memiliki koordinat $\mathrm{X}$ dan $\mathrm{Y}$ dapat digunakan sebagai Kerangka Kontrol Horisontal (KKH). Pengukuran KKH ini biasa menggunakan jaringan Triangulasi, poligon dan jaringan titik GPS.

\section{GPS (Global Positioning System)}

GPS (Global Positioning System) adalah sistem satelit navigasi dan penentuan posisi yang dimiliki dan dikelola oleh Amerika Serikat. Sistem ini di desain untuk memberikan posisi dan kecepatan tiga-dimensi serta informasi mengenai waktu, secara kontinyu di seluruh dunia tanpa bergantung waktu dan cuaca, bagi banyak orang secara simultan. Saat ini GPS sudah banyak digunakan orang di seluruh dunia dalam berbagai bidang aplikasi yang menuntut informasi tentang posisi, kecepatan, percepatan ataupun waktu yang teliti. GPS dapat memberikan informasi posisi dengan ketelitian bervariasi dari beberapa millimeter (orde nol) sampai dengan puluhan meter.

\section{METODE PELAKSANAAN}

\section{Kerangka Pemecahan Masalah}

Kerangka berfikir secara teoritis maupun empirik diterapkan untuk memecahkan masalah yang sudah diidentifikasi dan sudah dirumuskan. Proses pemilihan cara pemecahan yang paling baik dilakukan dalam kegiatan pengabdian kepada masyarakat tergambar dalam tahapan berikut : 


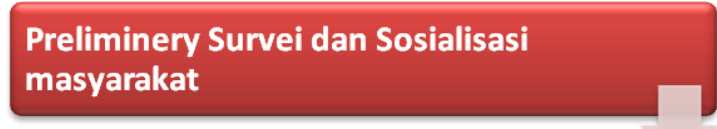

Preliminery Survei dan Sosialisasi

masyarakat

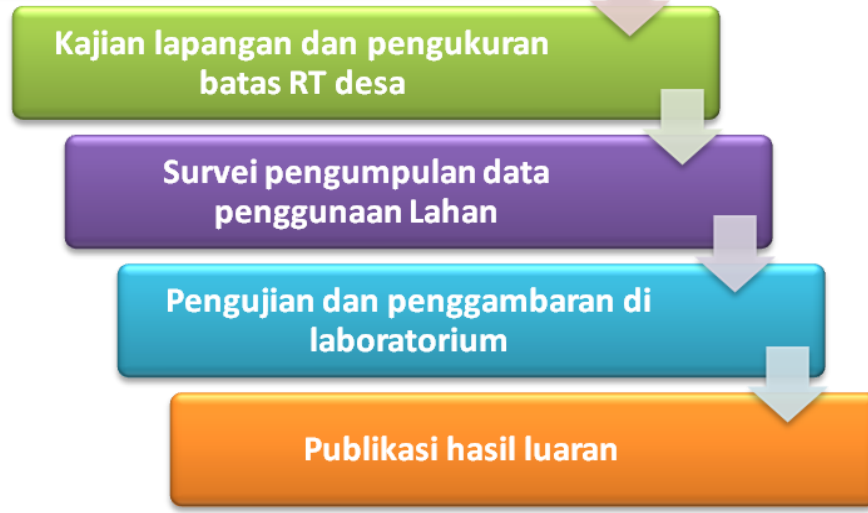

Gambar 1. Kerangka berfikir secara sistematis pelaksanaan survei dan pemetaan Batas Adminstrasi Desa.

Metode pengolahan data yang dilakukan dalam Pengabdian masyarakat dilaksanakan secara sistematis digambarkan pada diagram alir berikut :

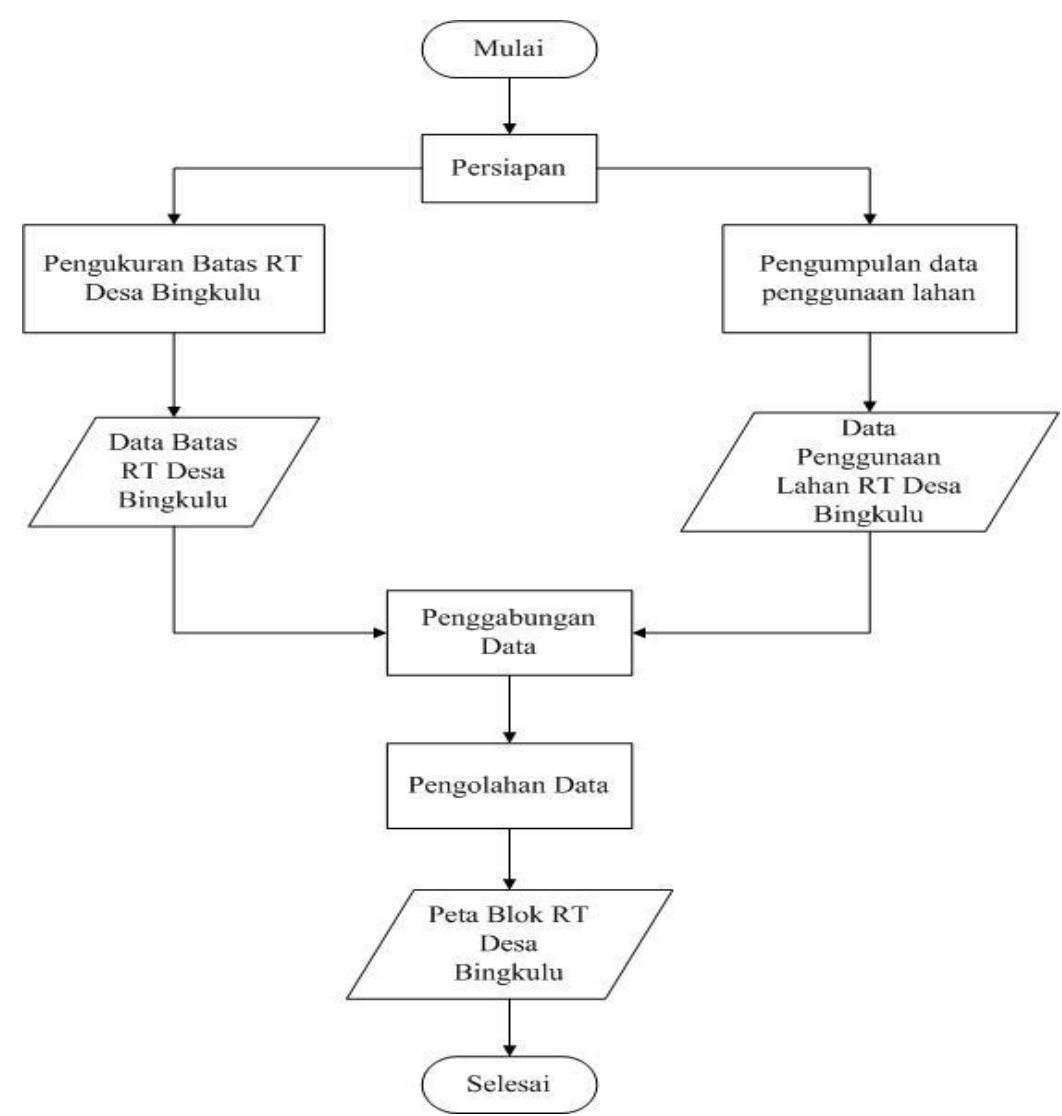

Gambar 2. Diagram Alir Pelaksanaan dan pengolahan data 
Penjelasan Diagram Alir :

1. Persiapan

Tahapan persiapan pengabdian ini dimulai dengan studi literatur mengenai pembuatan peta blok RT Desa Bingkulu. Setelah sudi literatur dilakukan langkah selanjutnya yaitu persiapan alat dan bahan yang digunakan dalam pembuatan peta tersebut di atas. Alat yang harus dipersiapan yaitu alat pengukuran terestris.

2. Pengukuran Batas RT dan Pengumpulan Data Penggunaan Lahan

Pada proses ini tim dibagi menjadi dua. Tim pertama bekerja pada proses pengukuran batas RT desa Bingkulu sehingga menghasilkan data batas RT Desa Bingkulu. Tim kedua bekerja dalam proses pengumpulan data penggunaan lahan yang menghasilkan data penggunaan lahan wilayah RT di Desa Bingkulu.

3. Penggabungan Data

Proses penggabungan data dilakukan antara data batas RT dan penggunaan lahan wilayah RT di Desa Bingkulu. Proses ini dilakukan dengan menggunakan software dalam bidang geodesi.

4. Pengolahan Data

Hasil penggabungan data di atas, selanjutnya diproses untuk pembuatan Peta Blok RT Desa Bingkulu. Dalam Peta ini akan menampilkan informasi tentang batas RT dan penggunaan lahan terbangun dan tidak terbangun di wilayah RT Desa Bingkulu.

\section{HASIL DAN PEMBAHASAN}

\section{Kondisi Umum}

Desa Bingkulu memiliki luas daerah administrasi sekitar 2.390 Ha. Sebalah Utara desa ini berbatasan dengan Desa Kayu Abang, Sebelah Selatan berbatasan dengan Desa Ujung Batu, Sebelah Timur berbatasan dengan polau Sari, Sebelah Barat berbatasan dengan Desa Maluka. 


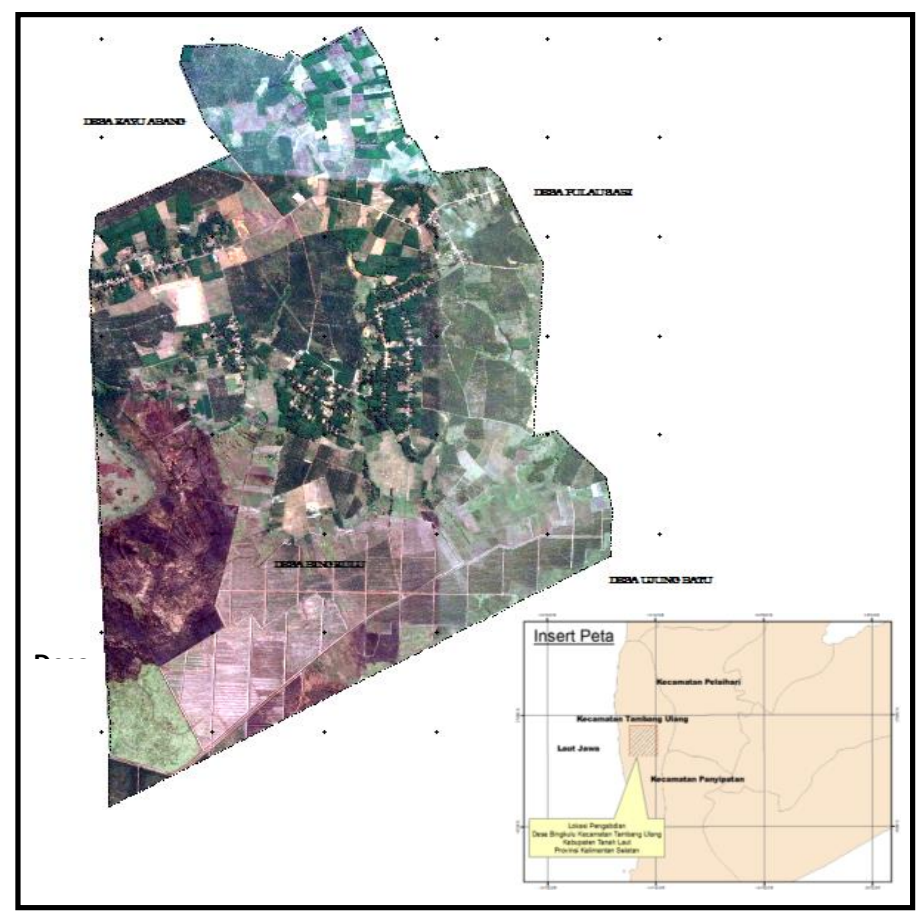

Gambar 3. Kondisi Umum Lokasi Pengabdian

\section{Hasil}

Desa Bingkulu memiliki batas administrasi yang tegas dan cukup luas. Hal ini ditunjukkan dengan sudah adanya informasi batas Desa Bingkulu. Namun permasalahan lain yang muncul yaitu belum adanya informasi batas RT dan penggunaan lahan di desa tersebut. Sehingga hasil yang didapatkan dalam penelitian ini yang pertama yaitu menyediakan peta batas RT dari Desa Bingkulu.

Untuk membuat peta batas RT di atas dilakukan dengan survey menggunakan GPS handheld mengelilingi dan mengidentifikasi batas RT sesuai arahan salah satu aparat desa yang sangat menguasai kondisi di lapangan. Pembuatan peta batas RT dilakukan memalui proses digitasi pada Aplikasi QGIS dengan menampilkan citra satelit yang sudah terkoreksi. Melalui aplikasi QGIS, digitasi dilakukan sesuai dengan kondisi dan keadaan di lokasi penelitian, dengan memperhatikan kenampakan rupa bumi pada citra satelit Desa Bingkulu. Adapun obyek yang didigitasi pada proses ini yaitu jalan, batas RT, batas Desa, fasilitas umum.

Selain itu informasi lain yang didapatkan dalam penelitian ini yaitu data penggunaan lahan di Desa Bingkulu. Data penggunaan lahan ini didapatkan dari proses interpretasi pada citra satelit dengan memanfaatkan aplikasi QGIS. Beberapa kenampakan penggunaan lahan pada citra satelit sesuai dengan gambar di bawah ini : 


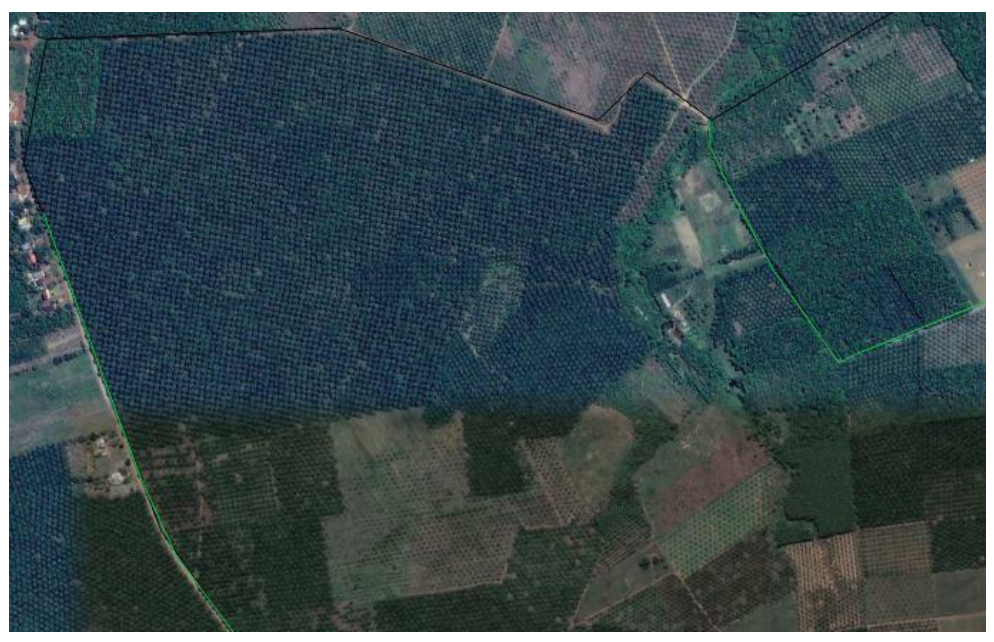

Gambar 5. Hasil Interpretasi Perkebunan Sawit di Desa Bingkulu

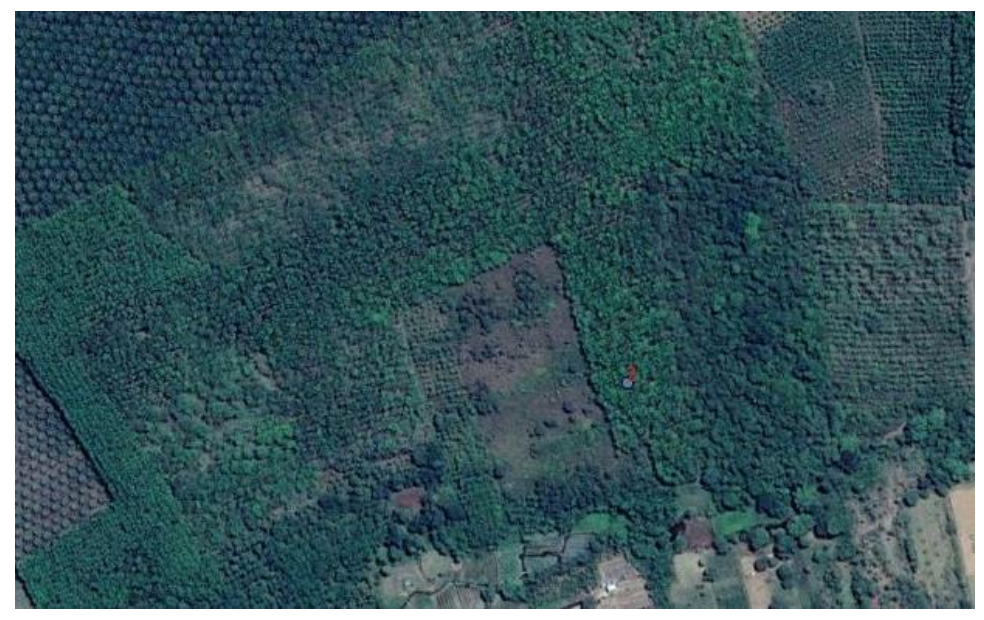

Gambar 6. Hasil Interpretasi Perkebunan Karet di Desa Bingkulu

\section{Analisis Hasil}

Berdasarkan hasil interpretasi yang telah dilakukan didapatkan bahwa penggunaan lahan di Desa Bingkulu meliputi perkebunan, sawah, dan lahan terbangun. Penggunaan lahan berupa perkebunan hampir merata diseluruh wilayah Desa Bingkulu dengan dua jenis komoditas yaitu pohon sawit dan karet. Adapun persebaran area perkebunan tersebut dapat dilihat dalam tabel di bawah ini : 
Tabel 1. Perbandingan Luas Perkebunan Sawit dengan Perkebunan Karet Setiap RT Desa Bingkulu

\begin{tabular}{|c|r|r|l|}
\hline RT & $\begin{array}{c}\text { Luas Perkebunan } \\
\left.\text { Sawit } \mathbf{( m}^{\mathbf{2}}\right)\end{array}$ & $\begin{array}{c}\text { Luas Perkebunan } \\
\left.\text { Karet } \mathbf{( m}^{\mathbf{2}}\right)\end{array}$ & Keterangan \\
\hline 1 & 2023347.71 & 1178876.50 & Dominan Sawit \\
2 & 79395.40 & 590287.00 & Dominan Karet \\
3 & 758041.72 & 610256.50 & Dominan Sawit \\
4 & 6851.96 & 33352.25 & Dominan Karet \\
5 & 0 & 15531.50 & Dominan Karet \\
6 & 0 & 153675.40 & Dominan Karet \\
7 & 580779.43 & 42672.60 & Dominan Sawit \\
8 & 550778.71 & 378551.24 & Dominan Sawit \\
9 & 621091.00 & 132889.50 & Dominan Sawit \\
\hline
\end{tabular}

Pada tabel di atas terlihat bahwa hampir di seluruh wilayah RT di Desa Bingkulu mempunyai penggunaan lahan perkebunan sawit dan karet, kecuali pada RT 5 dan RT 6 yang hanya memiliki perkebunan karet saja. Selain itu sesuai dengan hitungan pada tabel di atas terlihat bahwa penggunaan lahan di seluruh RT Desa Bingkulu didominasi oleh perkebunan sawit. Sehingga pohon sawit sampai saat ini masih menjadi komoditas utama dari perkebunan yang ada di Desa Bingkulu tersebut.

\section{KESIMPULAN}

Dari hasil pembahasan di atas didapatkan bahwa pembuatan peta Desa Bingkulu dilakukan dengan cara pemetaan di lapangan dan digitasi pada citra satelit dengan memanfaatkan aplikasi QGIS. Selain itu penelitian ini juga menjelaskan bahwa penggunaan lahan yang ada di Desa Bingkulu meliputi, perkebunan, sawah, dan lahan terbangun. Perkebunan sawit menjadi pengguaan lahan yang dominan muncul hampir diseluruh wilayah di Desa Bingkulu.

\section{DAFTAR PUSTAKA}

Brinker, R.C \& Wolf, P.R Edisi VII, Jilit 1, 1986, Dasar-Dasar Pengukuran Tanah (Surveying), Erlangga, Jakarta.

Danoedoro, P., 1996. Pengolahan Citra Digital: Teori dan Aplikasinya dalam Bidang Penginderaan Jauh. Fakultas Geografi Universitas Gajah Mada,Yogyakarta.

Lillesand, T. M., and Kiefer, R. W. 1994. Remote Sensing and Image Interpretation. John Wiley\&Son Inc,. New York.

Prahasta, E. 2001. Konsep-Konsep Dasar Sistem Informasi Geografis. Bandung : IF Informatika.

Prahasta, E., 2008. Remote Sensing, Informatika, Bandung. 
P3M, 2018, Pedoman Pelaksanaan Penelitian Dan Pengabdian Kepada Masyarakat, Banjarmasin.

Sosrodarsono, S, Dr, Cetak V, 2005, Pengukuran Topografi dan Teknik Pemetaan, Pradnya Paramita, Jakarta.

Sobatnu, F, Cetak I, 2006, Diktat Kuliah Ilmu Ukur Tanah, Politeknik Negeri Banjarmasin.

Sutanto, 1986, Penginderaan Jauh Jilid 1, Gadjah Mada University Press, Yogyakarta.

W.Whyte\& R.E. Paul, 1997, Basic Surveying, Butter Worth, Heineman 